\title{
KAJIAN HUKUM KEDUDUKAN BANGUNAN DI ATAS HAK PAKAI ATAS TANAH YANG TELAH DI BATALKAN (Di Tinjau Dari Peraturan Pemerintah Nomor 40 Tahun 1996 Tentang Hak Guna Usaha, Hak Guna Bangunan Dan Hak Pakai Atas Tanah)
}

\author{
Mahmud Jaelani dan Abdul Mukmin \\ jaelaniarema@gmail.com,mukmin@uwgm.ac.id \\ Fakultas Hukum Universitas Widya Gama Mahakam Samarinda
}

\begin{abstract}
ABSTRAK
Hak Pakai diatur dalam Pasal 41 sampai dengan Pasal 43 yang diatur lebih lanjut dalam Peraturan Pemerintah Nomor 40 tahun 1996 tentang Hak Guna Usaha, Hak Guna Bangunan dan Hak Pakai Atas Tanah Pasal 41 sampai dengan Pasal 58. Dalam Pasal 41 ayat (1) Undang-Undang Pokok Agraria, didefinisikan bahwa Hak Pakai adalah hak untuk menggunakan dan/atau memungut hasil dari tanah yang dikuasai langsung oleh negara atau tanah Hak Milik orang lain, yang memberi wewenang dan kewajiban yang ditentukan dalam keputusan pemberiannya oleh pejabat yang berwenang memberikannya atau dalam perjanjian dengan pemilik tanahnya, yang bukan perjanjian sewa menyewa atau perjanjian pengolahan tanah, segala sesuatu asal tidak bertentangan dengan jiwa dan ketentuan-ketentuan undang-undang ini.

Sehingga penyebab batalnya hak kedua kedudukan bangunan di atas hak pakai atas tanah yang sudah dibatalkan. Kedudukan bangunan dalam hal ini bukan hanya dalam arti fisik yang menyangkut lokasi dan besaran bangunan semata, lebih dari pada itu memiliki arti hukum yang menyangkut kedudukan hukum dari bangunan tersebut. Hal ini terkait dengan hak kepemilikan dan hak atas tanah yang melekat di atasnya. Metode yang digunakan dalam penelitian ini adalah penelitian penelitian normatif dengan peraturan perundang-undangan sebagai bahan hukum primer, buku, literatur sebagai bahan hukum sekunder dan informasi dan data sebagai bahan sekunder dari penelitian ini.

Pada prinsipnya hal yang menyebabkan Hak Pakai Atas Tanah dapat dibatalkan adalah berakhirnya jangka waktu atau dibatalkan oleh pejabat yang berwenang, pemegang hak pengelolaan atau pemilik tanah sebelum jangka waktunya berakhir,dilepaskan secara sukarela oleh pemegang haknya sebelum jangka waktunya berakhir,hak pakainya dicabut, diterlantarkan, tanahnya musnah dan pemegang Hak Pakai tidak memenuhi syarat sebagai pemegang Hak Pakai. Sedangkan terkait dengan kedudukan bangunan yang ada diatas Hak Pakai Atas Tanah oleh WNI yang telah dibatalkan bergantung pada perjanjian yang mengiringi saat proses hak pakai diberikan, namun bagi WNA melalui hak pakai dapat mengalihkan asetnya melalui kewarisan.
\end{abstract}

Kata Kunci: Hukum, Tanah, Hak Guna Bangunan dan Hak Pakai. 


\begin{abstract}
The right to use is regulated in Article 41 through Article 43 which is further regulated in Government Regulation No. 40 of 1996 concerning Right to Cultivate, Right to Build and Right to Use of Land Article 41 to Article 58. In Article 41 paragraph (1) of Law Basic Agrarian Law, is defined as the Right to Use is the right to use and / or collect proceeds from land that is directly controlled by the state or land of the Property of another person, who gives authority and obligations specified in the decision to grant it by an official authorized to give it or in an agreement with the owner of the land, which is not a lease agreement or land processing agreement, everything originating does not conflict with the spirit and provisions of this law.

So that the cause of the cancellation of the second right is the position of the building above the usufructuary rights to the land that has been cancelled. The position of the building this case is not only in the physical sense concerning the location and magnitude of the building alone, more than that it has a legal meaning concerning the legal position of the building. This is related to ownership rights and land rights attached to it. The method used in this study is a normative research study with legislation as primary legal material, books, literature as secondary legal material and information and data as secondary material from this study.

In principle, the matter that causes the Right to Use of Land can be canceled is the expiration of the term or canceled by the authorized official, the management right holder or the landowner before the expiry date, released voluntarily by the right holder before the term expires, the right of use is revoked, abandoned, the land is destroyed and the Right of Use holder does not qualify as the Right to Use holder. Whereas in relation to the position of the building above the Use of Land Rights by the Indonesian Citizen who has been cancelled depends on the agreement that accompanies when the right to use is granted, but for foreigners through the right to use can transfer their assets through inheritance.
\end{abstract}

Keywords: Law, Land, Building Use Rights and Use Rights.

\title{
PENDAHULUAN
}

\section{A. Latar Belakang}

Tanah merupakan kebutuhan dasar manusia, sejak lahir sampai meninggal dunia, manusia membutuhkan tanah untuk tempat tinggal hidupnya. Secara kosmologis, tanah adalah tempat manusia tinggal, tempat dari mana mereka berasal, dan akan kemana mereka pergi. Dalam hal ini, tanah mempunyai dimensi ekonomi, sosial, kultural, dan politik. Tanah sangat erat sekali hubungannya dengan kehidupan manusia, dimana setiap orang memerlukan tanah bukan hanya untuk kehidupannya, tapi sampai manusia meninggal dunia juga masih

tetap memerlukan tanah. Ini membuktikan bahwa sumber daya alam ini tidak dapat dipisahkan dari manusia sampai kapanpun. Dengan demikian penggunaan, penguasaan, dan pemanfaatan tanah untuk hidup dan kehidupan manusia perlu diatur sedemikian rupa sehingga tercipta keteraturan dalam hidup bermasyarakat. Mengingat tanah menjadi objek yang rawan terhadap sengketa, karena kebutuhan manusia akan tanah semakin meningkat namun persediaan tanah relatif tetap. 
Eksistensi tanah dalam kehidupan manusia mempunyai arti dan sekaligus memiliki fungsi ganda, yaitu sebagai sosial asset dan capital asset. Sebagai sosial asset tanah merupakan sarana pengikat kesatuan sosial di kalangan masyarakat untuk hidup dan kehidupan, sedangkan capital asset, tanah merupakan faktor modal dalam pembangunan dan telah tumbuh sebagai benda ekonomi yang sangat penting sekaligus sebagai bahan perniagaan dan obyek spekulasi. ${ }^{1}$

Sebagai karunia Tuhan sekaligus sumber daya alam yang strategis bagi bangsa, negara dan rakyat, tanah dapat dijadikan sarana untuk mencapai kesejahteraan hidup bangsa Indonesia sehingga perlu campur tangan negara untuk turut mengaturnya. Hal ini sesuai dengan amanat konstitusional sebagaimana tercantum pada Pasal 33 Ayat (3) UndangUndang Dasar 1945; "Bumi, air dan kekayaan alam yang terkandung didalamnya dikuasai oleh negara dan dipergunakan untuk sebesar-besarnya kemakmuran rakyat".

Mengingat peran tanah yang begitu besar maka negara berkewajiban untuk mengatur penggunaan dan peruntukan tanah, sebagai mana yang diatur dalam Pasal 33 ayat (3) Undang-Undang Dasar Tahun 1945 yang menyatakan "Bumi dan air dan kekayaan alam yang terkandung di dalamnya dikuasi oleh Negara dan dipergunakan untuk sebesar-besar kemakmuran rakyat". Bumi, air dan kekayaan alam yang terkandung didalamnya begitu pula ruang angkasa merupakan karunia Tuhan Yang Maha Esa kepada seluruh rakyat Indonesia dan oleh karena itu sudah semestinya pemanfaatannya haruslah

\footnotetext{
${ }^{1}$ Achmad Rubaie, Hukum Pengadaan Tanah Untuk Kepentingan Umum, Bayumedia, Malang, 2007, hlm 1.
}

ditunjukkan untuk memcapai sebesarbesarnya kemakmuran rakyat Indonesia.

Menurut kamus besar bahasa Indonesia tanah adalah permukaan bumi atau lapisan bumi yang diatas sekali. Sedangkan menurut Pasal 4 UndangUndang Nomor 5 Tahun 1960 yang selanjutnya disebut Undang-Undang Pokok Agraria dinyatakan "atas dasar hak menguasai dari negara sebagai yang dimaksud dalam pasal 2 ditentukan adanya macam-macam hak atas permukaan bumi yang disebut tanah, yang dapat diberikan kepada dan dipunyai oleh orang-orang baik sendiri maupun bersama-sama dengan orang lain serta badan-badan hukum".

Berdasarkan ketentuan pasal di atas yang dimaksud dengan istilah tanah adalah permukaan bumi. Perubahan sistem pelaksanaan Pemerintah dari sistem Pemerintahan masa orde baru menuju orde reformasi berpengaruh pada paradigma pembangunan pertanahan. Upaya menjabarkan paradigma pemerintahan dibidang pertanahan diwujudkan dengan sarana prasarana terhadap pelaksanaan tugas dalam bidang pelayanan pertanahan seperti dalam proses pemberian hak atas tanah.

Berdasarkan Undang-Undang Nomor 5 Tahun 1960 tentang Peraturan Dasar Pokok Agraria, Hak Pakai diatur dalam Pasal 41 sampai dengan Pasal 43 yang diatur lebih lanjut dalam Peraturan Pemerintah Nomor 40 tahun 1996 tentang Hak Guna Usaha, Hak Guna Bangunan dan Hak Pakai Atas Tanah Pasal 41 sampai dengan Pasal 58. Dalam Pasal 41 ayat (1) Undang-Undang Pokok Agraria, didefinisikan bahwa Hak Pakai adalah hak untuk menggunakan dan/atau memungut hasil dari tanah yang dikuasai langsung oleh negara atau tanah Hak Milik orang lain, yang memberi 
wewenang dan kewajiban yang ditentukan dalam keputusan pemberiannya oleh pejabat yang berwenang memberikannya atau dalam perjanjian dengan pemilik tanahnya, yang bukan perjanjian sewa menyewa atau perjanjian pengolahan tanah, segala sesuatu asal tidak bertentangan dengan jiwa dan ketentuan-ketentuan undang-undang ini.

Perkataan "menggunakan" dalam pengertian Hak Pakai sebagaimana tersebut diatas menunjuk pada pengertian bahwa Hak Pakai digunakan untuk kepentingan mendirikan bangunan. Sedangkan perkataan "memungut hasil" dari pengertian diatas adalah menunjuk pada pengertian bahwa Hak Pakai digunakan untuk kepentingan selain mendirikan bangunan, misalnya pertanian, perikanan, peternakan, perkebunan. $^{2}$

Berdasarkan definisi dan penjelasan singkat mengenai Hak Pakai Atas Tanah diatas, maka terdapat hubungan antara Hak Pakai Atas Tanah dengan Kedudukan bangunan yang mana salah satu fungsi Hak Pakai Atas Tanah adalah untuk mendirikan bangunan. ${ }^{3}$

Kedudukan bangunan dalam hal ini bukan hanya dalam arti fisik yang menyangkut lokasi dan besaran bangunan semata, lebih dari pada itu memiliki arti hukum yang menyangkut kedudukan hukum dari bangunan tersebut. Hal ini terkait dengan hak kepemilikan dan hak atas tanah yang melekat di atasnya.

Berdasarkan penjelasan singkat diatas, terdapat beberapa aspek yang dapat dibahas untuk menjadi alasan pemilihan judul skripsi ini. Aspek pertama adalah komponen-komponen yang melekat pada Hak Pakai yang kemudian menyebabkan adanya pembangunan bangunan diatas tanah dengan alas Hak Pakai Atas Tanah dapat

2 Urip Santoso,Hukum Agraria, Kajian Komprehensif, Kencana Prenada Media Group, Jakarta, 2012 hal 119. diwujudkan. Komponen tersebut diatur dalam Pasal 50 Peraturan Pemerintah Nomor 40 Tahun 1996 tentang Hak Guna Usaha, Hak Guna Bangunan dan Hak Pakai Atas Tanah mengenai Kewajiban dan Hak Pemegang Hak Pakai yang menyebutkan:

a. Membayar uang pemasukan yang jumlah dan cara pembayarannya ditetapkan dalam keputusan pemberian haknya, perjanjian penggunaan tanah Hak Pengelolaan atau dalam perjanjian pemberian Hak Pakai atas tanah Hak Milik.

b. Menggunakan tanah sesuai dengan peruntukannya dan persyaratan sebagaimana ditetapkan dalam keputusan pemberiannya, atau perjanjian pemberian Hak Pakai atas tanah Hak Milik.

c. Memelihara dengan baik tanah dan bangunan yang ada di atasnya serta menjaga kelestarian lingkungan hidup.

d. Menyerahkan kembali tanah yang diberikan dengan Hak Pakai kepada Negara, pemegang Hak Pengelolaan atau pemegang Hak Milik sesudah Hak Pakai tersebut hapus.

e. Menyerahkan sertipikat Hak Pakai yang telah hapus kepada Kepala Kantor Pertanahan.

Aspek kedua, Komponen yang dapat menimbulkan akibat hukum, sehingga Hak Pakai Atas Tanah tersebut dibatalkan. Pasal 55 ayat (1) Peraturan Pemerintah Nomor 40 Tahun 1996 tentang Hak Guna Usaha, Hak Guna Bangunan dan Hak Pakai Atas Tanah menerangkan bahwa hapusnya Hak Pakai dikarenakan :

a. Berakhirnya jangka waktu sebagaimana ditetapkan dalam keputusan pemberian

\footnotetext{
3 John Salindeo, Masalah Tanah Dalam Pembangunan,Cetakan Kedua ,Sinar Grafika, Jakarta, 2011, hal 44
} 
atau perpanjangannya atau dalam perjanjian pemberiannya.

b. Dibatalkan oleh pejabat yang berwenang, pemegang Hak Pengelolaan atau pemegang Hak Milik sebelum jangka waktunya berakhir, karena :

1. Tidak dipenuhinya kewajibankewajiban pemegang hak dan/atau dilanggarnya ketentuan-ketentuan sebagaimana dimaksud dalam Pasal 50, Pasal 51 dan Pasal 52; atau

2. Tidak dipenuhinya syarat-syarat atau kewajiban-kewajiban yang tertuang dalam perjanjian pemberian Hak Pakai antara pemegang Hak Pakai dan pemegang Hak Milik atau perjanjian penggunaan Hak Pengelolaan; atau

3. Putusan pengadilan yang telah mempunyai kekuatan hukum yang tetap.

Pembatalan Hak Atas Tanah dapat ditemukan di Pasal 34 huruf $\mathrm{b}$ dan Pasal 40 huruf b UUPA yang berbunyi " dihentikan sebelum jangka waktunya berakhir karena sesuatu syarat tidak dipenuhi', Pasal 1 angka 14 Peraturan Menteri Negara Agraria / Kepala Badan Pertanahan Nasional (PMNA/KBPN) Nomor 9 Tahun 1999 tentang Tata Cara Pemberian dan Pembatalan Hak Atas Tanah Negara dan Hak Pengelolaan : "pembatalan Hak Atas Tanah adalah pembatalan keputusan pemberian hak atas tanah atau sertipikat hak atas tanah karena keputusan tersebut mengandung cacat hukum administrasi dalam penerbitannya atau untuk melaksanakan putusan pengadilan yang sudah memperoleh kekuatan hukum tetap".

Badan Pertanahan Nasional (BPN) mempunyai kewenangan dalam membatalkan hak atas tanah. Hal ini tertera didalam Peraturan Kepala Badan Pertanahan Nasional Republik Indonesia Nomor 11 tahun 2016 tentang Penyelesaian Kasus
Pertanahan, peraturan ini, dalam melakukan pembatalan hak atas tanah, melakukan pembagian kewenangan, yakni kewenangan kementrian dan kewenangan bukan kementrian. Dalam pengelompokan kewenangan ini, Badan Pertanahan Nasional bisa melakukannya dengan dua cara, Cara yang pertama yaitu dengan menjalankan amar putusan pangadilan yang telah memperoleh kekuatan hukum tetap. Hal ini lebih rinci dijelaskan didalam Pasal 49 ayat (2) yang menyatakan bahwa amar putusan pengadilan yang telah memperoleh kekuatan hukum tetap, yang berkaitan dengan penerbitan, peralihan dan/atau pembatalan hak atas tanah, antara lain:

a. Perintah untuk membatalkan hak atas tanah.

b. Menyatakan batal/tidak sah/tidak mempunyai kekuatan hukum hak atas tanah;

c. Menyatakan tanda bukti hak tidak sah/ tidak berkekuatan hukum;

d. Perintah dilakukannya pencatatan atau pencoretan dalam buku tanah;

e. Perintah penerbitan hak atas tanah;

f. Perintah untuk membatalkan penetapan tanah terlantar; dan

g. Amar yang bermakna menimbulkan akibat hukum terbitnya, atau beralihnya atau batalnya hak.

Cara yang kedua adalah, Badan Pertanahan Nasional (BPN) melakukan pembatalan pemberian hak tanpa adannya putusan dari pengadilan. Klasifikasi permasalahan sengketa termuat secara rinci pada Pasal 11 ayat (3) Peraturan Kepala Badan Pertanahan Nasional Republik Indonesia Nomor 11 tahun 2016 tentang Penyelesaian Kasus Pertanahan

penyelesaian kasus pertanahan diluar pengadilan dapat berupa perbuatan hukum administrasi hal ini tersebut dalam Pasal 24, 25, 26. Sedangkan untuk mengenai pelaksanaan keputusan penyelesaian kasus 
pertanahan tersebut secara rinci pada Pasal 27, 28, 29, dimana keputusan penyelesaian sengketa atau konflik dilaksanakan oleh Kepala Kantor Pertanahan.

Pembahasan tentang hak pakai atas tanah cukup menarik untuk dibahas karena terdapat multi aspek hukum yang dapat menimbulkan problem hukum khususnya pada aspek pembatalan hak pakai atas tanah oleh pemerintah terhadap perorangan (persoon) dan/atau badan hukum (recht persoon), terlebih manakala hak pakai atas tanah tersebut melekat pada aset negara. Hal tersebut menggambarkan multi aspek diantarannya aspek hukum agraria, hukum administrasi negara dan hukum perdata.

\section{B. Permasalahan}

Dari uraian latar belakang yang sudah tertulis diatas, maka dapat dirumuskan masalah sebagai berikut :

1. Apa yang menyebabkan Hak Pakai Atas Tanah dapat dibatalkan?

2. Bagaimana kedudukan bangunan yang ada diatas Hak Pakai Atas Tanah yang telah dibatalkan?

\section{Tujuan dan Manfaat Penelitian}

Adapun tujuan dalam penelitian ini adalah untuk mengetahui dan menjelaskan apa yang menyebabkan hak pakai atas tanah ini dapat dibatalkan dan bagaimana kedudukan bangunan yang ada diatas tanah tersebut yang telah dibatalkan.

Adapun penelitian ini tidak hanya memberikan manfaat teoritis dan manfaat praktisi yaitu dapat memberikan kontribusi dalam pengembangan ilmu hukum khususnya pengembangan ilmu hukum perundang-undangan dan peraturan kebijakan agraria, dan bagi pemerintah diharapkan mampu sebagai bahan kajian dalam merumuskan suatu peraturan hukum yang terkait dengan masalah pengkajian dan penanganan masalah pertanahan yang dalam hal ini adalah kedudukan bangunan diatas Hak Pakai Atas Tanah yang telah dibatalkan.

\section{METODE PENELITIAN}

\section{A. Jenis Penelitian dan Sumber Data}

Penelitian yang digunakan dalam penelitian ini adalah penelitian normative, dengan peraturan perundang-undangan sebagai bahan hukum primer atau yang utamanya.

Adapun sumber data yang digunakan dalam penelitian ini adalah data sekunder yang terdiri dari berbagai bahan hukum seperti Undang-Undang Dasar Negara Republik Indonesia 1945, (amandemen ke4), Undang-Undang Nomor 5 Tahun 1960 tentang Dasar Pokok-pokok agraria, Peraturan Pemerintah Republik Indonesia Nomor 40 Tahun 1996 tentang Hak Guna Usaha, Hak Guna Bangunan, dan hak Pakai Atas Tanah, Peraturan Menteri Negara Agraria/Kepala Badan Pertanahan Nasional Nomor 3 Tahun 1999 tentang Pelimpahan Kewenangan Pemberian dan Pembatalan Keputusan Pemberian Hak Atas Tanah Negara, Peraturan Menteri Negara Agraria/Kepala Badan Pertanahan Nasional Nomor 9 Tahun 1999 tentang Tata Cara Pemberian dan Pembatalan Hak atas Tanah Negara dan Hak Pengelolaan, Peraturan Menteri Negara Agraria/Kepala Badan Pertanahan Nasional Nomor 11 Tahun 2016 tentang Penyelesaian Kasus Pertanahan. Bahan hukum sekunder yang berupaka buku-buku, junral, majalah, dan artikel yang terkait dengan penelitian. Dan bahan hukum tersier berupa kamus-kamus hukum dan ensiklopedia.

\section{B. Teknik Pengumpulan Data}

Tehnik yang dipergunakan dalam penelitian ini beupa studi kepustakaan yang dipergunakan untuk mengumpulkan bahanbahan hukum, baik bahan hukum primer yang berupa perundang-undangan maupun 
bahan hukum sekunder dan lainnya, dan wawancara dengan narasumber yang terkait dengan permasalahan dalam penelitian ini.

\section{Analisis Data}

Dalam penelitian ini, analisis data yang dilakukan yaitu mengkaji data-data yang diperoleh dari studi kepustakaan yang berupa literatur-literatur, dan peraturan perundang-undangan yang berkaitan dengan penelitian proposal skripsi ini, kemudian digabungkan dengan masalah yang akan diteliti menurut kualitas dan kebenaran.

\section{PEMBAHASAN}

\section{A. Penyebab Batal atau Berakhirnya Hak Pakai.}

Pembahasan tentang hak merupakan pembahasan yang akan selalu melekat dengan hukum. Hak merupakan sebuah kata yang akan berimplikasi besar terhadap hukum bukan hanya terkait dengan kepemilikan tetapi juga menyangkut kewajiban, larangan pembatalan hingga pencabutan atas hak tersebut.

Dalam suatu proses yudisial tidak jarang ditemukan problematik mengenai dapat atau tidaknya suatu hak digunakan sebagai dasar dalam mengajukan gugatan. Kondisi tersebut diakibatkan karena adanya kekaburan dan ketidakpastian mengenai hak yang ingin digunakan sebagai dasar untuk mengajukan gugatan.

Selama suatu hak tidak dilindungi oleh peraturan hukum, maka hak ini belum merupakan hak hukum ${ }^{4}$. Hak hukum merupakan hak seseorang dalam kapasitasnya sebagai subjek hukum yang secara legal tercantum dalam hukum yang berlaku. Adapun ciri dari suatu hak hukum yaitu hak tersebut diakui oleh hukum positif

${ }^{4}$ Hans Kelsen, 2006, Teori Umum Tentang Hukum dan Negara, Cetakan ke-1, Bandung : Nusa Media dan Nuansa, hlm. 113 serta enforcable di depan pengadilan. Hal tersebut dikukuhkan dengan suatu adagium dalam hukum yang menyatakan ubi jus ibi remedium (where there is a right there must be a remedy). ${ }^{5}$

Dari sisi hukum, hak hukum merupakan norma hukum dalam hubungannya dengan individu tertentu yang ditentukan oleh norma itu sendiri. Hak hukum tidak ditafsirkan sebagai suatu keinginan atau kepentingan yang tidak dikualifikasi, tetapi sebagai kepentingan yang dilindungi oleh aturan hukum, atau suatu keinginan yang diakui dan dibuat efektif oleh aturan hukum.

Demikian juga terkait dengan hak pakai, dijelaskan bahwah ak pakai merupakan hak yang dapat dimiliki oleh setiap warga negara, maka dari itu negara berdiri untuk memberikan perlindungan atas hah-hak tersebut sebagaimana diatur dalam pasal 41 ayat (1) Undang-Undang Nomor 5 Tahun 1960 tentang Peraturan Dasar Pokok Agraria. Hak pakai yang terjadi karena terdapatnya suatu peristiwa hukum yang mana telah diatur dalam berbagai peraturan perundang-undangan.

Lahirnya hak pakai diatur sedemikian rupa dalam berbagai peraturan perundangundangan sebagai syarat legalitas sebuah hak, sehingga hak tersebut menjadi sah baik materiil maupun formil untuk dapat mengikat para pihaknya. Demikian juga pada saat hak pakai tersebut batal kemudian hapus, negara juga mengatur prosedur, penyebab dan syarat-syarat pembatalannya.

Mengkaji hak pakai tentang pembatalan bukanlah hal yang mudah, prinsip kehati-hatian dan prinsip negara hukum menjadi hal yang harus diperhatikan dalam penetapan pembatalannya.

${ }^{5}$ Sakta Mahadiwya Prasetya, 2007, Hak Anak Untuk Memperoleh Pendidikan Sebagai Hak Asasi Manusia di Indonesia, Salatiga : FH UKSW, hlm. 83 
Pembatalan Hak Atas Tanah dapat ditemukan di Pasal 34 huruf b dan Pasal 40 huruf b UUPA yang berbunyi " dihentikan sebelum jangka waktunya berakhir karena sesuatu syarat tidak dipenuhi', Pasal 1 angka 14 Peraturan Menteri Negara Agraria / Kepala Badan Pertanahan Nasional (PMNA/KBPN) Nomor 9 Tahun 1999 tentang Tata Cara Pemberian dan Pembatalan Hak Atas Tanah Negara dan Hak Pengelolaan "pembatalan Hak Atas Tanah adalah pembatalan keputusan pemberian hak atas tanah atau sertipikat hak atas tanah karena keputusan tersebut mengandung cacat hukum administrasi dalam penerbitannya atau untuk melaksanakan putusan pengadilan yang sudah memperoleh kekuatan hukum tetap". Istilah "Pencabutan Hak Atas Tanah" secara formal dimunculkan dari Pasal 18 Undang-Undang Pokok Agraria yang mengatur "Untuk kepentingan umum, termasuk kepentingan bangsa dan negara serta kepentingan bersama rakyat, hak-hak atas tanah dapat dicabut, dengan menggantikan ganti kerugian yang layak dan menurut cara yang diatur dengan undangundang.

Pencabutan hak ialah pengambilan tanah kepunyaan penduduk atau sesuatu pihak oleh Negara secara paksa, yang mengakibatkan hak atas tanah menjadi hapus dan berpindah pihak terhadap siapa pencabutan dilakukan kepada pihak yang meminta pencabutan itu tanpa yang bersangkutan melakukan pelanggaran atau lalai dalam melakukan kewajiban hukumnya. Maka sesuai dengan ketentuan, bahwa pencabutan hak hanya dilakukan untuk kepentingan umum dan hanya dalam keadaan yang memaksa sebagai jalan yang terakhir untuk memperoleh tanah-tanah

${ }^{6}$ Bernhard Limbong, Pengadaan Tanah Untuk Pembangunan, Margaretha Pustaka, jakarta, 2011, Hlm 191 yang sangat diperlukan guna kepentingan umum. ${ }^{6}$ Berdasarkan pengertian mengenai pembatalan hak atas tanah dan pencabutan hak atas tanah tersebut diatas maka penulis menafsirkan bahwa pembatalan hak atas tanah sangatlah berbeda dengan pencabutan hak atas tanah, meskipun terdapat persamaan yang terletak pada akibat hukumnya yaitu hapusnya hak atas tanah.

Pencabutan hak atas tanah merupakan mekanisme secara sepihak dari pemerintah, namun tidak serta merta memberikan peluang kepada pemerintah untuk dengan leluasa mengambil tanah milik perorangan dengan dalil kepentingan umum, pemerintah wajib memperhatikan persyaratan menurut peraturan perundang-undangan ketika menggunakan upaya pencabutan hak atas tanah.

Pembatalan hak atas tanah sendiri merupakan perbuatan hukum yang tata cara dan prosedurnya telah diatur dalam peraturan perundan-undangan, pembatalan hak atas tanah itu lahir karena terdapatnya suatu keputusan yang mengandung cacat hukum administrasi dalam penerbitannya atau untuk melaksanakan putusan pengadilan yang sudah memperoleh kekuatan hukum tetap". Umumnya pembatalan hak atas tanah terjadi dikarenakan adanya suatu sengketa atau konflik masalah pertanahan yang harus diselesaikan, hal ini merupakan wujud pemerintahan dalam melakukan perlindungan terhadap warga negara demi terciptanya kepastian hukum yang bermanfaat dan berkeadilan sebagai konsekwensi Negara hukum.

Berdasarkan Pasal 55 ayat (1) Peraturan Pemerintah No. 40 Tahun 1996 tentang Hak Guna Usaha, Hak Guna 
Bangunan dan Hak Pakai Atas Tanah, Hak

Pakai hapus karena :

a. Berakhir jangka waktu;

Berakhirnya jangka waktu sebagaimana ditetapkan dalam keputusan pemberian atau perpanjangan atau dalam perjanjian pemberiannya;

b. Dibatalkan pejabat yang berwenang, pemegang hak pengelolaan atau pemegang hak milik sebelum jangka waktu berakhir karena:

1. Tidak dipenuhinya kewajibankewajiban pemegang Hak dan atau dilanggarnya ketentuan-ketentuan sebagaimana dimaksud dalam Pasal 50, Pasal 51 dan Pasal 52 atau

2. Tidak dipenuhinya syarat-syarat atau kewajiban-kewajiban yang tertuang dalam perjanjian pemberian Hak Pakai antara pemegang Hak Pakai dan pemegang Hak Milik atau perjanjian penggunaan hak pengelolaan; atau

c. Tidak dipenuhi kewajiban-kewajiban pemegang Hak Pakai.

1. Tidak membayar uang pemasukan yang jumlah dan cara pembayarannya ditetapkan dalam keputusan pemberian haknya, perjanjian penggunaan tanah Hak Pengelolaan atau dalam perjanjian pemberian Hak Pakai atas tanah Hak Milik.

2. Tidak menggunakan tanah sesuai dengan peruntukannya dan persyaratan sebagaimana ditetapkan dalam keputusan pemberiannya, atau perjanjian penggunaan tanah Hak Pengelolaan atau perjanjian pemberian Hak Pakai Atas Tanah Hak Milik.

3. Tidak memelihara dengan baik tanah dan bangunan yang ada diatasnya serta tidak menjaga kelestarian lingkungan hidup.

4. Tidak memberikan jalan keluar atau jalan air atau kemudahan lain bagi pekarangan atau bidang tanah yang terkurung oleh tanah Hak Pakai.

d. Tidak dipenuhi syarat atau kewajiban yang tertulis dalam perjanjian antara para pihak mengenai pemberian hak pakai atau penggunaan hak pengelolaan.

e. Putusan pengadilan yang telah mempunyai kekuatan hukum yang tetap.

f. Diberikan secara sukarela;

g. Ditelantarkan;

h. Tanahnya musnah;

i. Pemegang Hak Pakai tidak melepaskan atau mengalihan hak nya kepada pihak ketiga, dalam waktu satu tahun sejak pemegang Hak Pakai tidak lagi memenuhi persyaratan sebagai pemegang Hak Pakai sebagaimana diatur dalam Pasal 39 Peraturan Pemerintah Nomor 40 Tahun 1996 tentang Hak Guna Usaha, Hak Guna Bangunan dan Hak Pakai;

Pembatalan Hak Pakai Atas Tanah bisa terjadi apabila ke-4 point tersebut diatas salah satu diantaranya atau bahkan semuanya terjadi atau dilakukan oleh pemegang hak pakai maka kemungkinan terbesar pembatalan hak pakai atas tanah akan terjadi, meskipun pemegang hak pakai masih diberikan suatu perlindungan hukum oleh pemerintah melalui upaya hukum semisal banding, kasasi dan peninjauan kembali, dikarenakan mekanisme penyelesaian atas sengketa mengenai hak atas tanah dapat melalui jalur peradilan perdata dan peradilan tata usaha negara saja. Akibat dari pembatalan Hak Pakai Atas Tanah yang telah mempunyai kekuatan hukum tetap maka mempunyai akibat hukum Hapusnya Hak Pakai Atas Tanah.

Tujuan pengaturan pertanahan dalam Undang-Undang Nomor 5 Tahun 1960 tentang Peraturan Dasar Pokok Agraria adalah dalam rangka memberikan jaminan kepastian hukum bagi pemilik tanah dan untuk memberikan jaminan kepastian 
hukum maka dilaksanakan suatu mekanisme pendaftaran tanah di seluruh Indonesia. Demikian juga terkait dengan pembatalan hak atas tanah.

Defenisi pembatalan hak atas tanah yang diatur dalam Peraturan Menteri Negara Agraria/Keputusan Kepala Badan Pertanahan Nasional No. 9 Tahun 1999 tentang Pemberian dan Pembatalan Hak Milik atas Tanah Negara masih dapat digunakan mengingat aturan peralihan dalam Peraturan Kepala Badan Pertanahan Nasional (Perkaban) No. 3 Tahun 2011 tentang Pengelolaan Pengkajian dan Penanganan Kasus Pertanahan yakni dalam Pasal 84 menegaskan bahwa Ketentuan Peraturan Menteri Negara Agraria/Kepala Badan Pertanahan Nasional Nomor 9 Tahun 1999 tentang Tata Cara Pemberian dan Pembatalan Hak Atas Tanah Negara dan Hak Pengelolaan, sepanjang mengatur tata cara pembatalan Hak Atas Tanah Negara yang bertentangan dengan Peraturan ini dan defenisi pembatalan hak yang terdapat dalam Peraturan Menteri Negara Agraria/Kepala Badan Pertanahan Nasional Nomor 9 Tahun 1999 tentang Tata Cara Pemberian dan Pembatalan Hak Atas Tanah Negara dan Hak Pengelolaan tidak bertentangan dengan substansi hukum yang ada dalam Peraturan Kepala Badan Pertanahan Nasional (Perkaban) No. 3 Tahun 2011 tentang Pengelolaan Pengkajian dan Penanganan Kasus Pertanahan.

Ketentuan dalam Peraturan Kepala Badan Pertanahan Nasional (Perkaban) No. 3 Tahun 2011 tentang Pengelolaan Pengkajian dan Penanganan Kasus Pertanahan tidak secara khusus mengatur mengenai pembatalan hak atas tanah namun diatur dalam ketentuan mengenai penyelesaian kasus pertanahan pada Bab VII dengan memberikan pengaturan bahwa penyelesaian kasus pertanahan pada dasarnya ada 2 (dua) yaitu :

1) pelaksanaan putusan pengadilan dan
2) penyelesaian kasus pertanahan di luar pengadilan.

Pelaksanaan putusan pengadilan serta penyelesaian kasus pertanahan di luar pengadilan dapat melahirkan perbuatan hukum berupa pembatalan sertipikat hak atas tanah sehingga dapat dikatakan bahwa jika didasarkan pada Peraturan Kepala Badan Pertanahan Nasional (Perkaban) No. 3 Tahun 2011 tentang Pengelolaan Pengkajian dan Penanganan Kasus Pertanahan maka pembatalan hak atas tanah dapat dilakukan dengan 2 (cara) yakni 1) berdasarkan putusan pengadilan dan 2) tidak berdasarkan putusan pengadilan.

Pasal 55 Perkaban No. 3 Tahun 2011 tentang Pengelolaan Pengkajian dan Penanganan Kasus Pertanahan menegaskan bahwa Tindakan untuk melaksanakan putusan pengadilan yang telah memperoleh kekuatan hukum tetap, dapat berupa pelaksanaan dari seluruh amar putusan, pelaksanaan sebagian amar putusan dan/atauhanya melaksanakan perintah yang secara tegas tertulis pada amar putusan. Selanjutnya dalam ayat (2) ditegaskan bahwa amar putusan pengadilan yang telah memperoleh kekuatan hukum tetap, yang berkaitan dengan penerbitan, peralihan dan/atau pembatalan hak atas tanah, antara lain perintah untuk membatalkan hak atas tanah, menyatakan batal/tidak sah/tidak mempunyai kekuatan hukum hak atas tanah, menyatakan tanda bukti hak tidak sah/tidak berkekuatan hukum, perintah dilakukannya pencatatan atau pencoretan dalam buku tanah, perintah penerbitan hak atas tanah dan amar yang bermakna menimbulkan akibat hukum terbitnya, beralihnya atau batalnya hak.

Selanjutnya, mengenai Proses Perbuatan Hukum Administrasi Pertanahan Terhadap Keputusan/Surat Cacat Hukum Administrasi dalam Pasal 64 ayat (3) menyebutkan bahwa Surat 
permohonan/usulan sebagaimana dimaksud pada ayat (1) dilampiri data pendukung antara lain, sertipikat hak atas tanah yang kedapatan cacat hukum administrasi, hasil pengolahan data yang membuktikan adanya cacat hukum administrasi, salinan amar putusan pengadilan atau pertimbangan hakim dalam menjatuhkan putusan yang substansinya menyatakan tidak sah dan/ atau palsu dokumen yang digunakan dalam proses penerbitan sertipikat hak atas tanah, surat-surat lain yang mendukung alasan permohonan pembatalan.

Menghubungkan antara kedua pasal di atas bahwa Perkaban No. 3 Tahun 2011 tentang Pengelolaan Pengkajian dan Penanganan Kasus Pertanahan pada dasarnya memberikan pengaturan bahwa Pembatalan Sertipikat Hak atas Tanah yang didasarkan pada Putusan Pengadilan yang tidak secara tegas menyatakan batal sertipikat tetapi memiliki amar yang bermakna menimbulkan akibat hukum terbitnya, beralihnya atau batalnya hak dikategorikan sebagai pembatalan sertipikat hak atas tanah karena cacat admnistrasi sebagaiman dapat dilihat pada Pasal 6 ayat (3) huruf c yang memberikan pengaturan bahwa salah satu syarat dalam pengajuan pembatalan sertipikat karena cacat admnistrasi adalah salinan amar putusan pengadilan atau pertimbangan hakim dalam menjatuhkan putusan yang substansinya menyatakan tidak sah dan/ atau palsu dokumen yang digunakan dalam proses penerbitan sertipikat hak atas tanah.

Ketentuan dalam Pasal 64 ayat (3) Perkaban No. 3 Tahun 2011 tentang Pengelolaan Pengkajian dan Penanganan Kasus Pertanahan berarti pula bahwa pembatalan hak berdasarkan putusan pengadilan umum baik perdata maupun pidana dikategorikan sebagai pembatalan hak karena cacat admnistrasi dan hanya Putuan Peradilan Tata Usaha Negara yang dikategorikan sebagai cacat hukum karena hanya Putusan PTUN yang secara tegas memerintahkan pembatalan sertipikat hak atas sehingga pengkategorian lain mengenai pembatalan hak dalam perkaban No. 3 tahun 2011 tentang Pengelolaan Pengkajian dan Penanganan Kasus Pertanahan yaitu:

1. Pelaksanaan putusan pengadilan yang menyatakan batal sertipikat dan;

2. Pembatalan karena cacat admnistrasi yang terbagi menjadi 2 (dua) jenis yakni berdasarkan;

a. putusan pengadilan dan berdasarkan penelitian oleh Badan Pertanahan Nasional dan

b. pembatalan hak tanpa melalui Putusan Pengadilan.

Pengkategorian Pembatalan sertipikat hak atas tanah yang dilaksanakan berdasarkan putusan peradilan umum baik perdata maupun pidana sebagai cacat admistrasi dalam Perkaban No. 3 Tahun 2011 tentang Pengelolaan Pengkajian dan Penanganan Kasus Pertanahan menurut penulis merupakan pengkategorian yang tidak tepat karena Putusan Perdata ataupun pidana pada dasarnya tidak menyangkut administrasi dalam penerbitan hak tetapi menyangkut keabsahan pemilikan seseorang terhadap sebidang tanah yang dibuktikan dengan sertipikat. Sertipikat yang dibatalkan berdasarkan Putusan Perdata dilaksanakan bukan karena adanya kekeliruan dalam prosedur atau administrasi pada Kantor Pertanahan tetapi didasarkan pada Putusan yang menyatakan berhak atau tidaknya seseorang atas sebidang tanah di mana ketika proses penerbitan hak dilaksanakan, berhak tidaknya orang tersebut belum diketahui dan hal ini berarti Kantor Pertanahan tidak melakukan tindakan penerbitan yang mengandung cacat admnistrasi sehingga pembatalan sertipikat yang dilaksanakan jelas bukan karena cacat admnistrasi tetapi karena cacat hukum. Cacat hukumnya sertipikat tersebut 
didasarkan pada suatu Putusan Pengadilan yang in kracht. Kesimpulan penulis dalam hal ini adalah seluruh pembatalan sertipikat hak atas tanah yang dilaksanakan berdasarkan putusan pengadilan baik Tata Usaha Negara, Perdata maupun Pidana adalah pembatalan sertipikat karena cacat hukum bukan karena cacat admnistrasi.

Pembatalan sertipikat hak atas tanah karena cacat admnistrasi hanya dilaksanakan terhadap sertipikat yang diketahui secara di kemudian hari mengandung cacat dalam penerbitannya dan pembatalannya tidak membutuhkan putusan pengadilan tetapi dapat dilaksanakan oleh Badan Pertanahan Nasional setelah melalui mekanismemekanisme tertentu sehingga dapat diyakini bahwa secara nyata terdapat kekeliruan dalam admnistrasi ataupun prosedur penerbitan sertipikat hak tersebut. Penulis dalam hal ini lebih menyetujui pembagian pembatalan hak dalam Peraturan Menteri Negara Agraria / Kepala Badan Pertanahan Nasional (PMNA/KBPN) Nomor 9 Tahun 1999 tentang Tata Cara Pemberian dan Pembatalan Hak Atas Tanah Negara dan Hak Pengelolaan yakni karena cacat hukum dan karena cacat admnistrasi. Pembatalan hak karena cacat admnistrasi dalam KBPN No. 9 Tahun 1999 merupakan pembatalan hak tanpa melalui proses peradilan tetapi karena ditemukan kekeliruan dalam penerbitan.

Berkaitan dengan pembatalan sertipikat hak atas tanah karena cacat administrasi dan pembatalannya dilaksanakan tidak melalui putusan pengadilan, realitas saat ini menunjukkan bahwa jenis pembatalan seperti ini sangat jarang dilaksanakan oleh Badan Pertanahan Nasional meskipun telah sekian banyak masyarakat meminta hal tersebut melalui surat-surat pengaduan yang diajukan ke Kantor-kantor pertanahan, Kanwil BPN ataupun BPN RI. Banyak yang kemudian memberikan pandangan bahwa BPN tidak memiliki keberanian membatalkan sertipikat hak atas tanah meskipun mengetahui bahwa telah ada kekeliruan dalam penerbitannya. Pertanyaan yang kemudian menarik untuk dicermati adalah hal-hal apa saja yang dapat dikategorikan sebagai cacat admnistrasi yang dapat dibatalkan tanpa melalui putusan pengadilan.

Pertanyaan ini menjadi urgen untuk dijawab karena ketidakjelasan kategori cacat admnistrasi yang dapat dibatalkan oleh BPN tanpa Putusan Pengadilan menimbulkan keraguan bagi pihak BPN untuk melaksanakan pembatalan tersebut padahal peraturan-peraturan dalam bidang pertanahan memberikan kewenangan tersebut kepada BPN. Pertanyaan ini kerap diitanyakan oleh masyarakat ketika sertipikat mereka tumpang tindih kemudian mereka meminta BPN untuk melakukan pembatalam tanpa putusan pengadilan tetapi BPN memilih untuk menyarankan mereka menempuh jalur hukum. Jika ditelaah, sertipikat kedua yang terbit dalam sertipkat ganda jelas terbit tidak sesuai dengan prosedur karena prosedur yang benar adalah tidak diperbolehkan sebuah sertipikat diterbitkan di atas tanah yang telah dilekati oleh hak. Tetapi mengapa BPN memilih untuk tidak melaksanakan pembatalan tanpa putusan pengadilan.

Sertipikat ganda hanya merupakan salah satu contoh bentuk kesalahan admnistrasi/prosedur yang nyata dilakukan oleh BPN tapi kerap kali BPN tidak berani melakukan pembatalan dengan dasar cacat administrasi. Pasal 6 ayat (2) Perkaban No. 3 Tahun 2011 tentang Pengelolaan Pengkajian dan Penanganan Kasus Pertanahan menegaskan bahwa Cacat hukum administrasi sebagaimana dimaksud pada ayat (1) antara lain, kesalahan prosedur dalam proses penetapan dan/atau pendaftaran hak tanah, kesalahan prosedur dalam proses pendaftaran peralihan hak dan/atau sertipikat pengganti, kesalahan 
prosedur dalam proses pendaftaran penegasan dan/atau pengakuan hak atas tanah bekas milik adat, kesalahan prosedur dalam proses pengukuran, pemetaan dan/atau perhitungan luas, tumpang tindih hak atau sertipikat hak atas tanah, kesalahan subyek dan/atau obyek hak dan kesalahan lain dalam penerapan peraturan perundangundangan.

Pasal 64 Perkaban No. 3 Tahun 2011tentang Pengelolaan Pengkajian dan Penanganan Kasus Pertanahan mengatur pula bahwa permohonan/usulan perbuatan hukum administrasi pertanahan terhadap sertipikat hak atas tanah yang cacat hukum administrasi dapat diajukan oleh pihak yang berkepentingan/pemohon atau kuasanya. Pasal 65 mengatur bahwa pihak yang berkepentingan sebagaimana dimaksud dalam Pasal 64 ayat (1) aparatur BPN RI yang mengetahui data dan/atau warkah penerbitan hak atas tanah yang tidak sah mengenai substansi dan/atau proses penerbitannya, aparatur BPN RI mempunyai bukti adanya kesalahan prosedur administrasi penerbitan sertipikat hak atas tanah dan pihak yang dirugikan akibat terbitnya sertipikat hak atas tanah yang cacat. 7 (tujuh) jenis cacat admnistrasi yang disebutkan dalam Pasal 62 Perkaban No. 3 Tahun 2011 tentang Pengelolaan Pengkajian dan Penanganan Kasus Pertanahan menurut penulis masih membuthkan pengkajian lebih jauh karena jenis-jenis cacat admnistrasi tersebut masih menimbulkan begitu banyak pertanyaan. Sebagai contoh, jenis kesalahan prosedur dalam proses penetapan dan/atau pendaftaran hak tanah. Kesalahan prosedur seperti apa yang dikategorikan sebagai cacat yang dapat diajukan pembatalan hak tanpa melalui pengadilan? Ketika seseorang mengajukan permohonan pembatalan dengan dasar bahwa di atas tanah di kelurahan a telah diterbitkan sertipikat hak milik atas nama si $\mathrm{B}$ melalui proses pemberian hak padahal tanah tersebut merupakan tanah dengan status tanah bekas milik adat dapat disebut sebagai cacat admnistrasi dan dapat menjadi dasar pembatalan sertipikat tanpa putusan pengadilan?Poin yang harus digaris bawahi dalam contoh ini adalah siapa yang mengajukan permohonan pembatalan hak, dasar apa yang digunakan untuk mengajukan pembatalan hak dan bagaimana membuktikan kebenaran dasar dan dalil yang digunakan untuk mengajukan pembatalan hak.

Ketiga poin di atas perlu dikaji dalam kaitan dengan pembatalan sertipikat dengan dasar cacat admnistrasi sebagai berikut :

1. Jika pihak yang mengajukan adalah pihak lain yang merasa dirugikan maka dalam masalah ini terdapat sengketa antara pemegang hak dengan pihak yang mengajukan.

2. Jika dasar yang digunakan untuk mengajukan hak adalah tanda bukti kepemilikan tanah dengan status tanah bekas milik adat berarti diperlukan adanya pembuktian kebenaran tanda bukti kepemilikan tersebut misalnya kebenaran letak tanah yang dimaksud dalam tanda bukti yang diajukan.

3. pembuktian kebenaran dasar dan dalil yang diajukan oleh pemohon pembatalan tentu saja berhadapan dengan pembuktian kebenaran dasar dan dalil yang diajukan oleh pemegang hak dalam pendaftaran haknya.

Kesalahan prosedur dalam proses penetapan dan/atau pendaftaran hak hanya dapat dijadikan dasar pembatalan hak tanpa putusan pengadilan jika kesalahan tersebut tidak melibatkan dua pihak yang bersengketa dan pihak pemegang hak sendiri yang meminta pembatalan karena menemukan adanya kekeliruan dalam proses penetaapan atau pendaftaran hak misalnya pemegang hak menemukan bahwa tanah yang ia daftar diproses pemberian hak 
padahal pada saat bermohon hak, ia mengajukan bukti pemilikan tanah bekas milik adat.

Cacat hukum administrasi yang dapat mengakibatkan tidak sahnya suatu sertifikat hak atas tanah harus dikuatkan dengan bukti berupa: ${ }^{7}$

a. putusan pengadilan yang telah berkekuatan hukum tetap; dan/atau

b. hasil penelitian yang membuktikan adanya cacat hukum administrasi; dan/atau

c. keterangan dari penyidik tentang adanya tindak pidana pemalsuan surat atau

d. Keterangan yang digunakan dalam proses penerbitan, pengalihan atau pembatalan sertifikat hak atas tanah; dan/atau

e. surat-surat lain yang menunjukkan adanya cacat administrasi.

Namun masalah yang kemudian patut dicermati adalah "jika pembatalan hak dilaksanakan, hal ini berarti akan dilakukan proses pendaftaran hak sesuai dengan prosedur harus diulang. Terkait dengan tanggung jawab BPN terhadap hal ini, BPN seharusnya menanggulangi biaya-biaya permohonan hak ulang yang akan dilaksanakan. Terkait dengan hal tersebut kategori cacat administrasi ini membutuhkan pengaturan lebih lanjut terkait dengan mekanisme pembatalan serta konsekuensi-konsekuensi yang timbul dari pembatalan tersebut.

Kesalahan prosedur dalam proses pendaftaran peralihan hak dan/atau sertipikat pengganti membutuhkan pula kejelasan dalam pengaturannya. Kesalahan seperti apa yang dimaksud dalam hal ini. Ketika seseorang mengajukan permohonan pembatalan hak karena kesalahan dalam pendaftaran peralihan hak dan/atau sertipikat pengganti dan melibatkan sengketa antara dua pihak maka pembatalan hak membutuhkan adanya putusan pengadilan dan jika melibatkan satu pihak, maka pengulangan proses peralihannya atau penggantian sertipikatnya membutuhkan pengaturan terkait dengan konsekuensikonsekuensi yang akan timbul akibat pembatalan tersebut.

Demikian pula dengan jenis cacat yang lain yaitu kesalahan prosedur dalam proses pendaftaran penegasan dan/atau pengakuan hak atas tanah bekas milik adat, tumpang tindih hak atau sertipikat hak atas tanah serta kesalahan subyek dan/atau obyek hak. Untuk cacat admnistrasi karena kesalahan hasil pengukuran penulis berpandangan bahwa kesalahan hasil pengukuran tidak perlu ditindaklanjuti dengan pembatalan sertipikat tetapi cukup dengan perbaikan data tanpa adanya pembatalan hak.

Pembatalan sertipikat karena cacat admnistrasi dan dilaksanakan apabila secara nyata ditemukan adanya kekeliruan dalam penerbitan hak atas tanah misalnya sertipikat ditandatangani bukan oleh Kepala Kantor yang menjabat pada saat penandatanganan, sertipikat ditandatangani oleh pejabat selain Kepala Kantor namun tidak sesuai dengan kewenangan yang ditentukan oleh peraturan perundang-undangan, misalnya Kepala Seksi Pendaftaran Tanah dan Hak Tanah diberikan kewenangan untuk menandatangani Sertipikat dengan luas objek sampai 500 meter persegi namun ia menandatangani sertipikat seluas 1000 meter persegi.

Pembatalan sertipikat karena cacat admnistrasi dan dilaksanakan tanpa melalui putusan pengadilan hanya dapat

7 Marmin M Roosadijo,Tinjauan Pencabutan Hak Atas Tanah dan Benda-benda yang ada di atasnya, Ghalia Indonesia, Jakarta,1999, hal 66 
dilaksanakan jika tidak mengandung sengketa hak antara dua belah pihak dan apabila terdapat sengketa dalam suatu permohonan pembatalan sertipikat baik sengketa admnistrasi, sengketa hak ataupun indikasi tindak pidana maka BPN tidak dapat melakukan pembatalan sertipikat karena dibutuhkan suatu Putusan Pengadilan yang In kracht.

Pembatalan sertipikat karena cacat admnistrasi dilaksanakan apabila perubahan data pendaftaran tanah sudah tidak memungkinkan untuk dilakukan. Sepanjang masih memungkinkan adanya perbaikan data pendaftaran tanah maka sebaiknya tindakan yang dilakukan hanya sebatas perbaikan data pendaftaran tanah bukan pembatalan sertipikat.

Proses pembatalan sertipikat karena cacat admnistrasi membutuhkan pengaturan yang lebih jelas misalnya mengenai kategori cacat admnistrasi yang dapat dibatalkan tanpa melalui putusan pengadilan, mekanisme pembatalan sertipikat hak atas sertipikat yang mengandung cacat admnistrasi, konsekuensi-konsekuensi yang akan timbul akibat pembatalan tersebut dan cacat admnistrasi.

\section{B. Kedudukan Bangunan Yang Ada di Atas Hak Pakai Atas Tanah Yang Telah Dibatalkan.}

\section{a) Kedudukan Bangunan Di Atas Hak Pakai Milik Warga Negara atau Badan Hukum Indonesia.}

Dalam rangka pemanfaatan tanah yang dikuasai oleh Negara, UUPA mengatur adanya Hak Pakai. Menurut Pasal 41 ayat (1) Undang-Undang Nomor 5 Tahun 1960 tentang Peraturan Dasar Pokok Agraria, Hak Pakai adalah hak untuk menggunakan dan/atau memungut hasil dari tanah yang dikuasai langsung oleh negara atau tanah milik orang lain, yang memberi wewenang dan kewajiban yang ditentukan dalam keputusan pemberiannya oleh pejabat yang berwenang memberikannya atau dalam perjanjian dengan pemilik tanahnya yang bukan perjanjian sewa menyewa atau perjanjian pengolahan tanah, segala sesuatu asal tidak bertentangan dengan jiwa dan ketentuan dalam undang-undang ini. Menurut Pasal 43 ayat (1) Undang-Undang Nomor 5 Tahun 1960 tentang Peraturan Dasar Pokok Agraria sepanjang tanah yang dikuasai langsung oleh Negara maka hak pakai hanya dapat dialihkan kepada pihak lain dengan izin pejabat yang berwenang.

Menjadi hal yang penting untuk dibahas adalah ketika atas hak pakai berdiri bangunan-bangunan atau benda-benda yang kemudian menjadi aset pihak penerima hak pakai. Ketika hak pakai tersebut habis waktu atau dibatalkan akan berdampak hukum atas benda-benda yang ada di atasnya. Maka dari itu membicarakan hak pakai tidak akan terlepas dari perjanjian pendahulu yang mengiringi diterbitkannya hak pakai tersebut. Sehubungan dengan pelaksanaan hak pakai atas barang milik daerah ditetapkan/dilaksanakan dalam bentuk perjanjian. Maka suatu perjanjian pemberian hak pakai tanah ini harus mengikuti kaidahkaidah hukum perjanjian. Untuk sahnya suatu perjanjian diperlukan 4 (empat) syarat yang harus dipenuhi, yang diatur dalam Pasal 1320 KUH Perdata, yaitu: ${ }^{8}$

1. Sepakat mereka yang mengikatkan dirinya;

2. Cakap untuk membuat suatu perikatan;

3. Suatu hal tertentu;

4. Suatu sebab yang halal.

Syarat sahnya suatu perjanjian yang kesatu (sepakat mereka yang mengikatkan dirinya) dan syarat kedua (cakap untuk

\footnotetext{
${ }^{8}$ R Subekti, Hukum Perikatan, PT.Pradya Paramitha, Jakarta, 1995, hal 24
} 
membuat suatu perjanjian) disebut syarat subjektif, karena menyangkut subjek hukum yaitu orang-orang atau pihak-pihak yang membuat perjanjian. Sedangkan syarat ketiga (objek suatu hal tertentu) dan syarat keempat (sebab atau causa yang halal) disebut sebagai objektif, karena menyangkut objek hukum yang diperjanjikan oleh orangorang atau pihak-pihak yang membuat perjanjian tersebut. ${ }^{9}$ Penting untuk diperhatikan atas perjanjian yang dibuat sebelum adanya hak pakai karena bendabenda yang ada di atasnya akan dipisahkan dengan tanah yang menjadi objek hukum hak pakai. Tanah yang melekat hak pakai dapat diberikan untuk kepentingan umum dimana selanjutnya kepemilikan atas bendabenda dan aktifitas di atasnya menjadi tanggungjawab pemerintah dengan menjadi aset negara.

Pada prinsipnya hak pakai merupakan aset negara jadi ketika hak pakai tersebut telah dibatalkan dan terdapat bangunan di atasnya maka sesungguhnya pemilik hak pakai tidak memiliki perhitungan hukum untuk kenguasaan apalagi kepemilikan aset di atas hak pakai. Hal ini berhubungan dengan hak guna bangunan. Ketika tanah hak pakai adalah aset negara maka ada baiknya subyek hukum mengurus hak guna bangunan, karena hal ini akan menjadi perhitungan atau pertimbangan hukum saat hak pakai telah habis masa waktu atau batal.

Namun berkemungkinan juga ketika hak pakai diberikan untuk kesejahteraan sekelompok masyarakat atau individu maka benda-benda tersebut akan dikembalikan kepada pemiliknya dengan cara dialihkan melalui jual beli atau hibah. Hal ini dibutuhkan jangka waktu. Tidak dapat dilakukan pembiaran untuk benda-benda yang ada di atas tanah eks hak pakai. Jika terlalu lama maka negara dapat melelang benda-benda yang ada di atasnya dengan mengembalikan hasil lelang kepada pemilik aset tersebut.

Hal ini akan berlaku lain ketika subyek hukum dari hak pakai tersebut adalah warga negara asing. Sub bab berikutnya akan membahas hal tersebut.

\section{b) Kedudukan Bangunan Di Atas Hak Pakai Milik Warga negara atau Badan Hukum Asing.}

Pemerintah menerbitkan Peraturan Pemerintah No. 103 Tahun 2015 tentang Pemilikan Rumah Tempat Tinggal atau Hunian oleh Orang Asing yang Berkedudukan di Indonesia.

Hal ini mengundang banyak perdebatan hukum. Namun yang jelas, ketentuan mengenai kepemilikan rumah tempat tinggal atau hunian asing di Indonesia telah ada sejak lama. Sebelum terbitnya PP 103 tahun 2015 ini, ketentuan mengenai kepemilikan rumah tempat tinggal atau hunian bagi Warga Negara Asing (WNA) di Indonesia diatur oleh Peraturan Pemerintah No. 41 Tahun 1996 Tentang Pemilikan Rumah Tempat Tinggal atau Hunian oleh Orang Asing yang Berkedudukan di Indonesia. Kehadiran PP 103/2015 Tentang Pemilikan Rumah Tempat Tinggal atau Hunian oleh Orang Asing yang Berkedudukan di Indonesia ditujukan untuk mengatur ulang kepemilikan properti oleh asing serta mencabut dan menggantikan PP 41/1996 Tentang Pemilikan Rumah Tempat Tinggal atau Hunian oleh Orang Asing yang Berkedudukan di Indonesia tidak lagi berlaku.

Peraturan Pemerintah No 103 Tahun 2015 tentang Pemilikan Rumah Tempat

\footnotetext{
9 Muhammad Syaifuddin, 2012,Hukum Perjanjian, Mandar Maju, Bandung, Hal.110
} 
Tinggal atau Hunian oleh Orang Asing yang Berkedudukan di Indonesia secara tegas menyatakan bahwa WNA yang tinggal di Indonesia dengan izin tinggal yang sah dapat memiliki rumah tempat tinggal atau rusun (apartemen) dengan Hak Pakai. Sedangkan Hak Milik, hanya dapat diberikan kepada WNI berdasarkan Undang-Undang No. 5 Tahun 1960 tentang Peraturan Dasar PokokPokok Agraria (UU Pokok Agraria).

Peraturan Pemerintah No. 103 Tahun 2015 tentang Pemilikan Rumah Tempat Tinggal atau Hunian oleh Orang Asing yang Berkedudukan di Indonesia tidak memperbolehkan WNA untuk memiliki rumah atau hunian dengan hak atas tanah jenis lainnya, seperti contoh Hak Milik. Dengan kata lain, WNA dapat menggunakan tanah dan bangunan sebagai tempat tinggal, namun kepemilikan tanah atau bangunan tersebut masih dimiliki negara atau Warga Negara Indonesia. Ketentuan serupa juga telah ada pada Peraturan Pemerintah No. 41 Tahun 1996 tentang Pemilikan Rumah Tempat Tinggal Atau Hunian Oleh Orang Asing Yang Berkedudukan Di Indonesia.

Ada beberapa ketentuan baru pada PP 103/2015 Tentang Pemilikan Rumah Tempat Tinggal atau Hunian oleh Orang Asing yang Berkedudukan di Indonesia yang sebelumnya tidak diatur oleh PP 41/1996.

Beberapa hal yang berubah dari kedua peraturan pemerintah tersebut di atas adalah :

1. WNA hanya dapat membeli rumah atau rusun (apartemen) unit baru.

2. Rumah yang dimiliki WNA wajib berdiri di atas:

a. tanah Hak Pakai; atau

b. Hak Pakai di atas Hak Milik. Sedangkan apabila WNA ingin memiliki apartemen, unit apartemen tersebut harus berdiri di tanah Hak Pakai.
3. Peraturan Pemerintah No 103 tahun 2015 Tentang Pemilikan Rumah Tempat Tinggal atau Hunian oleh Orang Asing yang Berkedudukan di Indonesia mengubah durasi Hak Pakai WNA terhadap rumah atau apartemen, menjadi:

a. Rumah di atas tanah Hak Pakai: masa Hak Pakai 30 tahun, dapat diperpanjang untuk 20 tahun, dan diperbaharui untuk 30 tahun (total durasi Hak Pakai 80 tahun).

b. Rumah di atas Hak Pakai di atas Hak Milik: masa Hak Pakai 30 tahun, dapat diperpanjang dan diperbaharui sesuai kesepakatan dengan pemilik tanah sampai dengan 30 tahun (total durasi Hak Pakai 60 tahun).

c. Apartemen: durasi Hak Pakai tidak diatur oleh PP 103/2015. Sebelumnya, Peraturan Pemerintah no 41 tahun 1996 membatasi durasi Hak Pakai WNA sampai dengan 25 tahun dan dapat diperpanjang sampai dengan 25 tahun, tanpa bisa diperbaharui (total durasi Hak Pakai 50 tahun).

4. WNA yang meninggal dunia dapat mewariskan hunianya kepada orang lain. Apabila ahli warisnya adalah WNA, maka ahli waris tersebut wajib memiliki izin tinggal yang sah untuk mewarisi hunian tersebut. Apabila tidak, hunian tersebut harus harus dialihkan kepada orang yang berhak dalam waktu satu tahun untuk menghindari hunian tersebut dilelang oleh negara (apabila dibangun di atas tanah negara) atau dikembalikan kepada yang mempunyai Hak Milik atas tanah dan bangunan.

5. WNI yang kawin dengan WNA tidak serta merta kehilangan haknya untuk mempunyai rumah atau tanah dengan Hak Milik atau hak lainnya. Namun, antara pasangan WNI dan WNA wajib 
memiliki perjanjian pemisahan harta antara suami dan isteri yang dibuat dengan akta notaris.

Penerbitan peraturan tersebut di atas menurut penulis merupakan kemuduran yang cukup lama pada Peraturan Pemerintah No 103 tahun 2015 Tentang Pemilikan Rumah Tempat Tinggal atau Hunian oleh Orang Asing yang Berkedudukan di Indonesia tidak memiliki landasan berpikir yang jelas dan menunjukan pemerintah tidak berpikir jauh kedepan.

Durasi Hak Pakai ini juga bertentangan dengan durasi Hak Pakai yang diatur oleh Peraturan Pemerintah No. 40 Tahun 1996 tentang Hak Guna Usaha, Hak Guna Bangunan dan Hak Pakai Atas Tanah , yang menyatakan Hak Pakai diberikan paling lama 25 tahun. Jika dibandingkan dengan durasi Hak Pakai untuk keperluan investasi yang diatur oleh Undang-Undang No. 25 Tahun 2007 tentang Penanaman Modal, yang hanya mebatasi maksimal 70 tahun.Mengenai durasi hak pakai ini seharusnya pemerintah terlebih dahulu merevisi Peraturan Pemerintah No. 40 Tahun 1996 tentang Hak Guna Usaha, Hak Guna Bangunan dan Hak Pakai Atas Tanah agar tidak terjadi tumpang tindih ketentuan durasi Hak Pakai. Selain itu, diperbolehkanya Hak Pakai diberikan secara turun-temurun bertengan dengan UU Pokok Agraria. Padahal berdasarkan Pasal 42 UUPA, Hak Pakai hanya bisa diberikan kepada Warga Negara Indonesia (WNI), orang asing yang berkedudukan di Indonesia, badan hukum yang didirikan menurut hukum Indonesia dan berkedudukan di Indonesia, serta badan hukum asing yang mempunyai perwakilan di Indonesia.

Peraturan Pemerintah No 103 tahun 2015 tetang Pemilikan rumah tempat tinggal atau hunian oleh orang asing yang berkedudukan di Indonesia seharusnya mengatur juga ketentuan mengenai batas harga, luas, dan jumlah hunian yang dapat dibeli oleh WNA. Dengan absennya batasan ini, dikhawatirkan WNA dapat membeli rumah murah pada saat rakyat Indonesia sendiri sulit untuk mendapatkan rumah.

Banyak kalangan mengkritik pemerintah yang cenderung lebih memikirkan WNA dengan menerbitkan Peraturan Pemerintah No 103 tahun 2015 tetang Pemilikan rumah tempat tinggal atau hunian oleh orang asing yang berkedudukan di Indonesia dibanding memfasilitasi lahan kepada petani dengan mengesahkan Rancangan Peraturan Pemerintah tentang Jaminan Luas Lahan Pertanian.

Akan lebih baik kepemilikan hunian oleh WNA harus diikuti dengan persyaratan. Pemerintah harusnya menggunakan sistem zonasi. Melalui sistem ini, WNA hanya diperbolehkan untuk membeli hunian pada daerah-daerah tertentu saja. Selain itu, pemerintah pusat harus melibatkan pemerintah dearah dalam menyusun kebijakan mengenai kepemilikan hunian oleh WNA, karena sebagian besar hunian WNA terdapat di daerah-daerah.

Peraturan Pemerintah No 103 tahun 2015 tetang Pemilikan rumah tempat tinggal atau hunian oleh orang asing yang berkedudukan di Indonesia juga menegaskan, bahwa Warga Negara Indonesia yang melaksanakan perkawinan dengan Orang Asing dapat memiliki hak atas tanah yang sama dengan Warga Negara Indonesia lainnya. "Hak atas tanah sebagaimana dimaksud, bukan merupakan harta bersama yang dibuktikan dengan perjanjian pemisahan harta antara suami dan istri, yang dibuat dengan akta notaris," bunyi Pasal 3 ayat (2) Peraturan Pemerintah No 103 tahun 2015 tetang Pemilikan rumah tempat tinggal atau hunian oleh orang asing yang berkedudukan di Indonesia. Adapun rumah tempat tinggal atau hunian yang dapat 
dimiliki oleh Orang Asing sebagaimana dimaksud merupakan:

a. Rumah Tunggal di atas tanah:

1. Hak Pakai; atau

2. Hak Pakai di atas Hak Milik yang dikuasai berdasarkan perjanjian pemberian Hak Pakai di atas Hak Milik dengan akta Pejabat Pembuat Akta Tanah.

b. Sarusun (satuan rumah susun) yang dibangun di atas bidang tanah Hak Pakai.

Menurut Peraturan Pemerintah No 103 tahun 2015 tetang Pemilikan rumah tempat tinggal atau hunian oleh orang asing yang berkedudukan di Indonesia ini, Rumah Tunggal yang diberikan di atas tanah Hak Pakai yang dapat dimiliki Orang Asing diberikan untuk jangka waktu 30 (tiga puluh) tahun, dan dapat diperpanjang untuk jangka waktu 20 (dua puluh) tahun. Dalam hal jangka waktu perpanjangan sebagaimana dimaksud berakhir, Hak Pakai dapat diperbaharui untuk jangka waktu 30 (tiga puluh) tahun. Adapun Rumah Tunggal di atas tanah Hak Pakai di atas Hak Milik yang dikuasai berdasarkan perjanjian sebagaimana dimaksud diberikan Hak Pakai untuk jangka waktu yang disepakati tidak lebih lama dari 30 (tiga puluh) tahun.

Hak Pakai dapat diperpanjang untuk jangka waktu paling lama 20 (dua puluh) tahun sesuai kesepakatan dengan pemegang hak atas tanah, dan dapat diperbaharui untuk jangka waktu paling lama 30 (tiga puluh) tahun sesuai kesepakatan dengan pemegang hak atas tanah."Perpanjangan dan pembaharuan sebagaimana dimaksud dilaksanakan sepanjang Orang Asing masih memiliki izin tinggal di Indonesia," bunyi Pasal 8 Peraturan Pemerintah No 103 tahun 2015 tetang Pemilikan rumah tempat tinggal atau hunian oleh orang asing yang berkedudukan di Indonesia itu.
Peraturan Pemerintah No 103 tahun 2015 tetang Pemilikan rumah tempat tinggal atau hunian oleh orang asing yang berkedudukan di Indonesia ini juga menegaskan, apabila Orang Asing atau ahli waris yang merupakan Orang Asing yang memiliki rumah yang dibangun di atas tanah Hak Pakai atau berdasarkan perjanjian dengan pemegang hak atas tanah tidak lagi berkedudukan di Indonesia, dalam jangka waktu 1 (satu) tahun wajib melepaskan atau mengalihkan hak atas rumah dan tanahnya kepada pihak lain yang memenuhi syarat.

Apabila dalam jangka waktu sebagaimana dimaksud (1 tahun) hak atas rumah dan tanahnya tersebut belum dilepaskan atau dialihkan kepada pihak lain yang memenuhi syarat, menurut Peraturan Pemerintah No 103 tahun 2015 tetang Pemilikan rumah tempat tinggal atau hunian oleh orang asing yang berkedudukan di Indonesiaini, rumah dilelang oleh Negara, dalam hal dibangun di atas tanah Hak Pakai atas tanah Negara; dan rumah menjadi milik pemegang hak atas tanah yang bersangkutan, dalam hal rumah tersebut dibangun di atas tanah berdasarkan perjanjian sebagaimana dimaksud.

"Hasil lelang sebagaimana dimaksud pada ayat (2) huruf a menjadi hak dari bekas pemegang hak," bunyi Pasal 10 ayat (3) Peraturan Pemerintah No 103 tahun 2015 tetang Pemilikan rumah tempat tinggal atau hunian oleh orang asing yang berkedudukan di Indonesia ini.

\section{PENUTUP KESIMPULAN DAN SARAN}

Adapun kesimpulan dari penelitian bahwa hal yang dapat menyebabkan berakhirnya hak pakai atas tanah seperti berakhirnya jangka waktu atau dibatalkan oleh pejabat yang berwenang, pemegang hak pengelolaan atau pemilik tanah sebelum jangka waktunya berakhir, dilepaskan secara 
sukarela oleh pemegang haknya sebelum jangka waktunya berakhir, hak pakainya dicabut, diterlantarkan, Tanahnya musnah, dan pemegang Hak Pakai tidak memenuhi syarat sebagai pemegang Hak Pakai.

Kedudukan bangunan yang ada diatas Hak Pakai Atas Tanah I yang telah dibatalkan dan ketika bangunan tidak memiliki hak atas bangunan maka pemilik hak atas pakai tersebut tidak memiliki perhitungan hukum.

Adapun saran yang diberikan dalam penelitian ini agar terciptanya kepastian hukum pemerintah haruslah bisa memfasilitasi pelayanan terkait dengan hak pakai dengan tidak mengeluarkan aturan dan kebijakan yang kenetralannya masih harus dipertanyakan. Masyarakat harus juga mendaftarkan hak pakai yang dimiliki sebagai bentuk kepastian hukum atas hak lain yang timbul sebagai dampak dari hak pakai yang melekat tersebut dan pemerintah masih perlu mensinkronkan peraturan perundang-undangan dan kebijakan baik yang berupa Peraturan Pemerintah atau peraturan menteri atau lembaga negara yang berwenang di bidang pertanahan dengan UUPA serta yang menjadi cita-cita dari reformasi agraria di Indonesia. Bagi Masyarakat perlu dengan baik memperhatikan hal yang dapat membatalkan hak pakai serta harus merawat dengan baik objek hak pakai agar dapat terjaga kepastian hukum kepemilikannya.

\section{DAFTAR PUSTAKA}

\section{Buku-buku :}

Achmad Rubaie, Hukum Pengadaan Tanah Untuk Kepentingan Umum, Bayumedia, Malang, 2007

Aminuddin Salle, Hukum Pengadaan Tanah Untuk Kepentingan Umum, Cetakan
Pertama, Kreasi Total Media, Jogjakarta, 2007

A.P Parlindungan, Hak Pengelolaan Menurut Sitem UUPA, Mandar Maju, Bandung. 2012 
Bernhard Limbong, Konflik Pertanahan, Margaretha Pustaka, Jakarta, 2012

Boedi Harsono, Hukum Agraria Indonesia : sejarah pembentukan undan-undang pokok agraria,Djambatan, Jakarta, 2007

Hukum Agraria Indonesia, Himpunan Peraturan-Peraturan Hukum Tanah , Djambatan, Jakarta, 2002

Bambang Eko Supriyadi, Aspek Hukum pertanahan Dalam Pengelolaan, Rajawali Pers, Jakarta,2013

John Salindeo, Masalah Tanah Dalam Pembangunan,Cetakan Kedua ,Sinar Grafika, Jakarta, 2011

Maria S.W Sumardjono, Reprientasi Kebijakan Pertanahan, Kompas, Jakarta, 2006

Marmin M Roosadijo,Tinjauan Pencabutan Hak Atas Tanah dan Benda-benda yang ada di atasnya, Ghalia Indonesia, Jakarta,1999.

Peter Mahmud Marzuki, penelitian hukum, Jakarta, Kencana 2005.

Suratman dan Philips Dillah, Metode Penelitian hukum, Bandung; Alfabeta. 2012

Supriadi, Hukum Agraria, Sinar Grafika, Jakarta, 2010.

Soerjono Soekonto, Pengantar Penelitian Hukum,Universitas Indonesia jakarta, 2000

R Subekti, Hukum Perikatan, PT.Pradya Paramitha, Jakarta, 1995

Urip Santoso, Hukum Agraria dan Hak-hak Atas Tanah, Kencana ,Jakarta, 2010.
Hukum Agraria Kajian

Komprehensif, Kencana

Prenadamedia Group, Jakarta, 2012

\section{Perundang-undangan:}

Undang-Undang 1945 Amandemen IV

Undang-Undang Nomor 5 Tahun 1960 tentang Peraturan Dasar Pokok Agraria

Undang-Undang No. 25 Tahun 2007 tentang Penanaman Modal.

Peraturan Pemerintah Nomor 40 Tahun 1996 tentang Hak Guna Usaha, Hak Guna Bangunan dan Hak Pakai

Peraturan Pemerintah No 103 tahun 2015 tetang Pemilikan rumah tempat tinggal atau hunian oleh orang asing yang berkedudukan di Indonesia.

Peraturan Pemerintah No. 41 Tahun 1996 Tentang Pemilikan Rumah Tempat Tinggal atau Hunian oleh Orang Asing yang Berkedudukan di Indonesia

Peraturan Menteri Negara Agraria / Kepala Badan Pertanahan Nasional (PMNA/KBPN) Nomor 9 Tahun 1999 tentang Tata Cara Pemberian dan Pembatalan Hak Atas Tanah Negara dan Hak Pengelolaan.

Peraturan Kepala Badan Pertanahan Nasional no 3 Tahun 2011 tentang Pengelolaan Pengkajian dan Penanganan Kasus Pertanahan

Peraturan Kepala Badan Pertanahan Nasional Republik Indonesia Nomor 11 tahun 2016 tentang Penyelesaian Kasus Pertanahan 
Pertanahan Nasional Nomor 3 Tahun 1999 tentang Pelimpahan Kewenangan Pemberian dan Pembatalan Keputusan Pemberian Hak Atas Tanah Negara

Lampiran Peraturan Menteri Negara Agraria/Kepala Badan Pertanahan Nasional No. 3 Tahun 1997 tentang Ketentuan Pelaksanaan Peraturan Pemerintah Nomor 24 Tahun 1997 tentang Pendaftaran Tanah. 